\title{
IMPACT OF NATURAL CAPITAL INVESTMENT STRATEGIES ON WATER QUALITY IN THE NDEMBERA RIVER SUB-CATCHMENT, TANZANIA
}

\author{
NORBERT J. NGOWI ${ }^{1} \&$ ADELAIDE E. SALLEMA ${ }^{2}$ \\ ${ }^{1}$ Institute of Development Studies, Mzumbe University, Tanzania \\ ${ }^{2}$ Museum and House of Culture, National Museum of Tanzania, Tanzania
}

\begin{abstract}
Natural capital investment strategies are a highly important tool in the sustainability of ecosystem services - including water and improved community livelihoods worldwide. However, their implications on the quality of water are hardly known in many societies of Tanzania. This paper reports the effect of one of such strategy, called Wetland Friendly Investment (WFI), on the quality of water on small parts of Ndembera sub-catchment of Tanzania, where (WFI) has been implemented for more than a decade. Samples of water were collected from the seven locations in the dry and wet seasons using 1,500 ml plastic tubes. Bottles with samples were labeled, stored in the cooling box and transported to the laboratory for analysis. All parameters were measured using standardized methods. To determine the effect of the strategy, we compared the measured mean difference values of the physicochemical properties of water before and after the introduction of the strategy using a two-way Analysis of Variance (ANOVA). The results showed that there was a statistically significant difference in Total Suspended Solids $($ TSS $)$ before $(p=0.0066)$ and after $(p=0.0324)$ the intervention. Msugulika stream and the upstream of Ndembera River had the highest value for Ammonia-Nitrogen, with means of 0.3 and $0.23 \mathrm{mg} / \mathrm{l}$ in the dry and wet seasons, respectively. The use of agrochemicals was mentioned as one of the contributing factors in the poor quality of water and this could not significantly be reduced by the introduction of the WFI strategy alone. Therefore, more robust actions are required in addressing the issue of the quality of water in the sub-catchment.
\end{abstract}

Keywords: Ndembera River sub-catchment, physicochemical, wetlands friendly investment, natural capital.

\section{INTRODUCTION}

More than one billion people are depending on wetlands for ecosystem services - including water, fishing, agriculture, flood control and climate regulation [1]. The quality of water in this ecosystem is of paramount significance for society development. However, the degradation of wetlands is one of the major global problems [2] that has reduced the wetlands area cover by almost $50 \%$ in the past century therefore threatening the quality of water worldwide [3]. Various studies in Tanzania has identified changes in land use, over-use of water in irrigation, sedimentation, invasive alien species, and climate change to have contributed about degradation of $90 \%$ of the wetlands in the country [3], [4].

In the light of the growing pressure on the wetlands and the services they support, the Government of Tanzania has introduced a number of natural capital strategies - including the strategy called Wetlands Friendly Investment (WFI) in the 2000s [5]. Theoretically, supporting the local community with incentives would make them reduce pressure on these natural systems henceforth provision of the services to the society [6]. The main objective of the strategy was to balance the protection and utilization at the heart of the wise use concept. Despite the introduction of this strategy, little is known on the effect of its implementation on the quality of water in the areas implemented [7].

This study aimed to fill this gap by investigating the effect of the implementation of this strategy on the quality of water in Ndembera area, Tanzania. This area was selected 
because the water in the basin supports many communities in Southern Tanzania, especially during the dry season when there is a water shortage. Data on the quality of water is important for developing proper land use as well as water treatment innovation methods in this catchment and beyond.

\section{MATERIALS AND METHODS}

\subsection{The study area}

This study was conducted in the section of Ndembera River Sub catchment which lies between latitudes $7^{\circ} .57^{\prime} .09^{\prime \prime}$ and $8^{\circ} 13^{\prime} .25^{\prime \prime} \mathrm{S}$ and longitudes $35^{\circ} 05.16^{\prime \prime}$ and $35^{\circ} 37.49^{\prime \prime} \mathrm{E}$ in Iringa District, Ngowi [3] (Fig. 1). It covers about $1,223 \mathrm{~km}^{2}$ within the Great Ruaha River (GRR). The later drains an area of about $68,000 \mathrm{~km}^{2}$. The climate is characterized by three distinct climatic zones - the highland, Midland and the lowland zone depending on the topography [3]. The long rain season runs between late March to June and the short ones November to February [8]. It is the only potential river contributing to about $500 \mathrm{~m}^{3}$ of the total inflow to Ihefu wetlands [8]. The catchment is an important area for natural resources conservation [8]. Agriculture, fishing, and livestock keeping are the main economic activities in the study area.

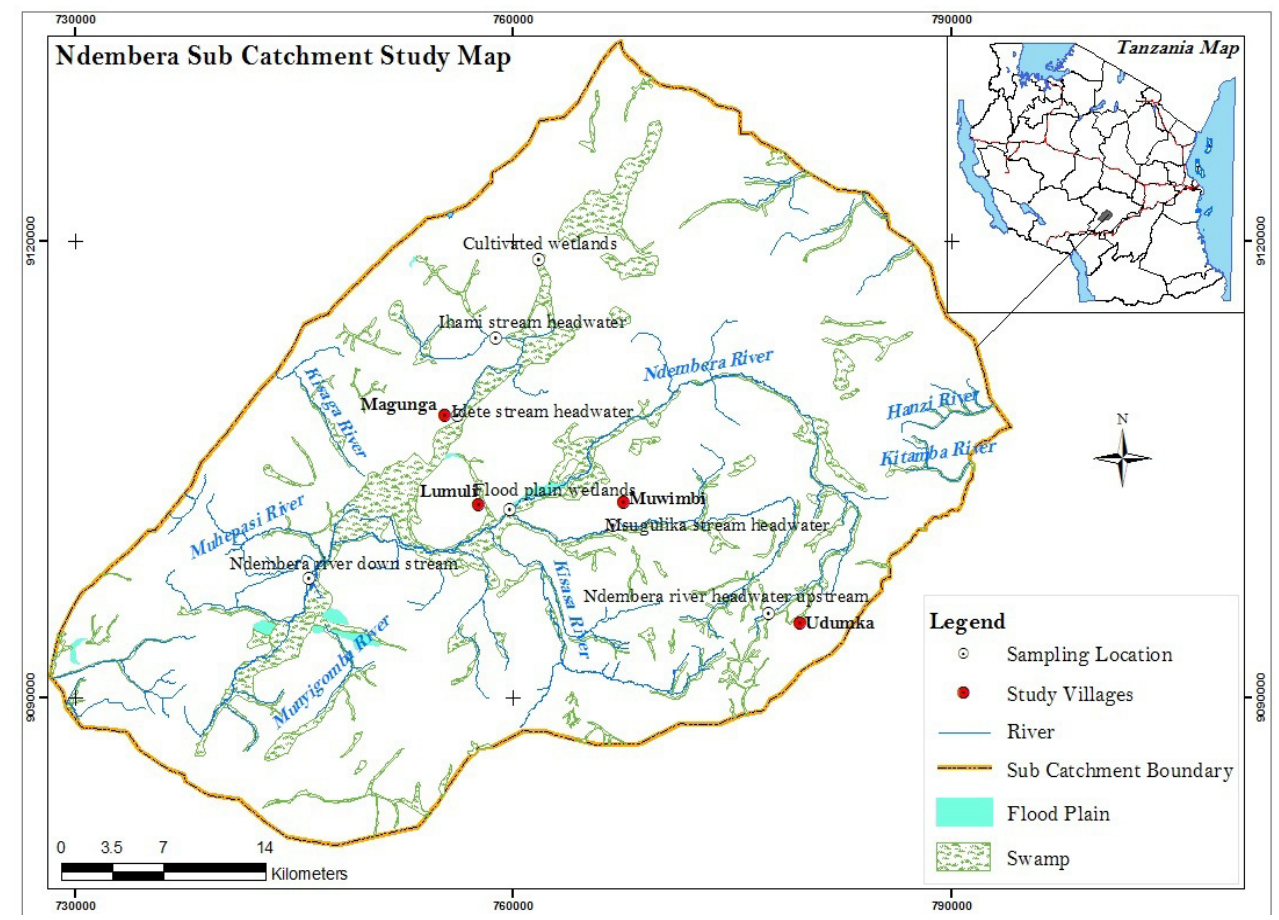

Figure 1: Map of the study area. Modified from Ngowi [3]. 


\subsection{Methods}

\subsubsection{Sampling locations}

Seven locations where the WFI strategy was introduced were selected. They included: cultivated wetlands, Ihemi stream, Ndembera, flood plain wetlands, Msugulika and Idete stream.

\subsubsection{Collection of water samples}

The water samples were collected from the depth of $15 \mathrm{~cm}$ in each of the seven locations in the month of September 2015 which represented the peak of the dry season and February 2016 for the wet season respectively. Water samples were stored in the $1500 \mathrm{ml}$ clean corked plastic bottle that have been pre-washed with Nitric Acid and thoroughly rinsed with distilled water [9]. The sampling locations were selected based on ease of access and in such a way that the samples represent the entire sub catchment. The bottles with the sample were labelled $\mathrm{SP}_{1}, \mathrm{SP}_{2}, \mathrm{SP}_{3}, \mathrm{SP}_{4}, \mathrm{SP}_{5}, \mathrm{SP}_{6}$, and $\mathrm{SP}_{7}$ based on the locations and kept in the cooling box, then transported to the laboratory for analysis.

\subsubsection{Experimental design}

Water quality analysis was carried out using standard analytical methods. Data were subjected to the Complete Randomized Design (CRD). ANOVA for each variable was conducted using MSTAT C software Program [10]. The mean values were separated by Duncan's Multiple Range Test (DMRT) to test for the significant difference at $\mathrm{p}<0.05$ [11].

\subsubsection{Analysis of the quality of water}

Water samples were filtered through a $5 \mu \mathrm{m}$ glass fiber filter and analyzed for both physical and chemical characteristics including - temperature, $\mathrm{pH}$, Electrical Conductivity (EC), Total Suspended Solids (TSS), Turbidity, Dissolved Oxygen (DO), Nitrate-Nitrogen $\left(\mathrm{NO}_{3}-\mathrm{N}\right)$, Ammonia-Nitrogen $\left(\mathrm{NH}_{4}-\mathrm{N}\right)$, Phosphate-Phosphorous $\left(\mathrm{PO}_{4}-\mathrm{P}\right)$ and Total Alkalinity as $\mathrm{CaCO}_{3}$ using standard method [12]. A transparent $30 \mathrm{~cm}$ plastic ruler was used to measure water depth. Odor, color, and temperature were measured using standard method [12] at the time of sampling. The temperature was measured using a thermometer. Distilled water was used to rinse the electrode between successive measurements. $\mathrm{pH}$ was determined using a pH meter (Toshniwal Instr. Pvt. Ltd No. 54) previously calibrated with a buffer solution with $\mathrm{pH}$ 7.0. Electrical Conductivity (EC) was determined using Systronics Conductivity Meter - 304 and recorded in micro Siemens per $\mathrm{cm}(\mu \mathrm{s} / \mathrm{cm})$. Total Suspended Solids (TSS) was determined by filtering a known volume of sample through a thoroughly dried filter paper and the residue weighed in $\mathrm{mg} / \mathrm{l}$. The Total alkalinity was determined by the titration method and expressed as $\mathrm{mg} \mathrm{CaCO} / 1$. Dissolved Oxygen (DO) was determined by Dissolved Oxygen meter, while Cadmium reduction method was used in the determination of Nitrate-nitrogen $\left(\mathrm{NO}_{3}-\mathrm{N}\right)$. Ammonia-nitrogen $\left(\mathrm{NH}_{4}-\mathrm{N}\right)$ was determined by Phenolnitroprusade method and Phosphate-phosphorous ( $\left.\mathrm{PO}_{4}-\mathrm{P}\right)$ was determined by Ascorbic acid method.

\section{RESULTS}

The results obtained from the analysis are presented in Table 1 and detailed separately in the Appendices I and II of the supplemental information enclosed. The mean values of the physicochemical quality of water at the locations along different seasons are presented in Table 2 and Table 3 respectively. 


\begin{tabular}{|c|c|c|c|c|c|c|c|c|c|c|c|c|c|}
\hline \multirow{12}{*}{ 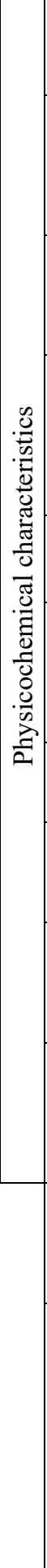 } & 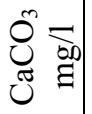 & $\stackrel{\infty}{\sim}$ & N & ঃ্ & $r$ & $\tilde{m}$ & $f$ & 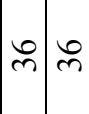 & $\begin{array}{l}0 \\
m\end{array}$ & ¿ి & $\therefore \approx$ & $\stackrel{n}{\sim}$ & $\begin{array}{l}\stackrel{ }{+} \\
\dot{+}\end{array}$ \\
\hline & 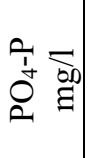 & $\begin{array}{l}J \\
0 \\
\dot{0} \\
v\end{array}$ & $\begin{array}{l}\text { ஓे } \\
8 \\
8 \\
8 \\
8 \\
0\end{array}$ & $\begin{array}{l}\dot{1} \\
\dot{0} \\
v\end{array}$ & $\begin{array}{l}8 \\
8 \\
8 \\
8 \\
8 \\
0\end{array}$ & $\begin{array}{l}\text { J } \\
0 \\
V \\
V\end{array}$ & $\mid \begin{array}{l}n \\
8 \\
0 \\
0 \\
0 \\
0\end{array}$ & 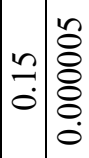 & $\overrightarrow{0}$ & \begin{tabular}{l|l} 
\pm \\
\\
8 \\
8 \\
\\
0
\end{tabular} & 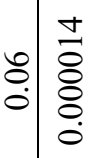 & @ & 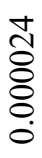 \\
\hline & 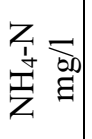 & $\begin{array}{c}- \\
\dot{0} \\
v\end{array}$ & 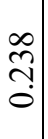 & $\begin{array}{l}\overrightarrow{0} \\
v\end{array}$ & $\begin{array}{l}\stackrel{8}{ } \\
\text { స్}\end{array}$ & $\begin{array}{l}\overrightarrow{0} \\
V\end{array}$ & 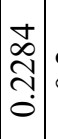 & 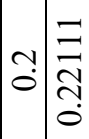 & 3 & 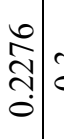 & 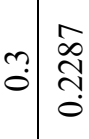 & $\begin{array}{l}\overrightarrow{0} \\
V\end{array}$ & 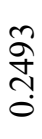 \\
\hline & 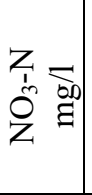 & $\begin{array}{c}\sim \\
\stackrel{0}{0} \\
v \\
\end{array}$ & $\mid \begin{array}{l}- \\
8 \\
8 \\
8 \\
8 \\
0 \\
0\end{array}$ & 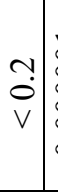 & $\begin{array}{l}\overline{8} \\
8 \\
8 \\
8 \\
0 \\
0\end{array}$ & $\begin{array}{l}\text { Na } \\
\text { v }\end{array}$ & $\mid \begin{array}{l}- \\
0 \\
0 \\
0 \\
0 \\
0\end{array}$ & 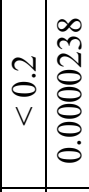 & 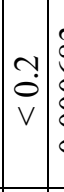 & 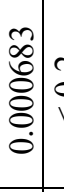 & 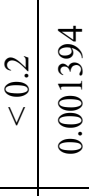 & ָั & $\begin{array}{l}\frac{1}{n} \\
\frac{n}{8} \\
0\end{array}$ \\
\hline & 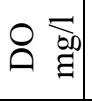 & $\approx$ & 守 & $\approx$ & $\stackrel{n}{n}$ & $n$ & $\mid$ & \begin{tabular}{l|l}
$i$ & $n$ \\
\multirow{f}{*}{} & 0
\end{tabular} & in & \begin{tabular}{|l} 
\pm \\
$\dot{n}$
\end{tabular} & $n \quad \begin{array}{l}\stackrel{8}{0} \\
\dot{0}\end{array}$ & $n$ & ๑ \\
\hline & 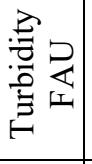 & 吕 & 요 & 음 & $ㅇ$ & $\begin{array}{l}0 \\
n \\
n\end{array}$ & $\simeq$ & $\because \cong$ & $\stackrel{n}{v}$ & $0: 4$ & $n \infty$ & $\begin{array}{l}\text { n } \\
m \\
m\end{array}$ & $a$ \\
\hline & 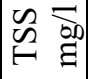 & $\wp$ & i & 二 & $\simeq$ & ్ి & $=$ & $=\infty$ & 이 & $\approx$ & 0 in & $r$ & $m$ \\
\hline & 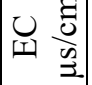 & 8 & む゙ & $\mathbb{N}$ & ก & $\stackrel{n}{r}$ & 吉 & $\infty$ & $\infty$ & $\infty$ & $\stackrel{\overbrace{}}{\approx}$ & $\mid$ & $\stackrel{\infty}{2}$ \\
\hline & 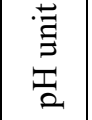 & $\underset{\sim}{\infty}$ & 丘 & $\stackrel{\infty}{\sim}$ & 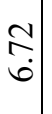 & $\stackrel{?}{r}$ & 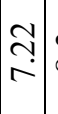 & $\infty$ & $\begin{array}{l}0 \\
-1\end{array}$ & $\stackrel{n}{r}$ & \begin{tabular}{l|l}
0 \\
\hdashline \\
\hdashline & $\infty$ \\
0
\end{tabular} & $\vec{r}$ & $\stackrel{2}{2}$ \\
\hline & 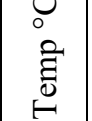 & ন & $\begin{array}{c}0 \\
\text { ते } \\
\end{array}$ & $\left|\begin{array}{l}n \\
\dot{0} \\
\sim\end{array}\right|$ & $\begin{array}{l}\stackrel{0}{2} \\
\grave{\lambda}\end{array}$ & $\begin{array}{l}n \\
\infty \\
i \\
\sim\end{array}$ & $\begin{array}{c}0 \\
\dot{\lambda}\end{array}$ & \begin{tabular}{l|l}
0 & 0 \\
$\grave{\lambda}$ & $\dot{\sim}$ \\
\end{tabular} & $\stackrel{-}{\grave{2}}$ & 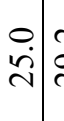 & $\begin{array}{ll} & 0 \\
& \ddot{n}\end{array}$ & $\begin{array}{l}\infty \\
\dot{\infty} \\
\sim\end{array}$ & $\begin{array}{l}0 \\
\ddot{i}\end{array}$ \\
\hline & 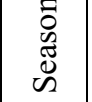 & $\overrightarrow{0}$ & $\mid \begin{array}{l}0 \\
3\end{array}$ & 至 & $\stackrel{\Delta}{3}^{\overline{0}}$ & $\overrightarrow{0}$ & $\overrightarrow{0}^{ \pm}$ & $\overrightarrow{0}$ & 至 & $\sum^{0}$ & $\vec{\theta} \sum_{3}^{\overrightarrow{0}}$ & & $i^{4}$ \\
\hline & 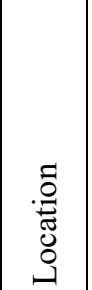 & & 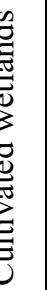 & 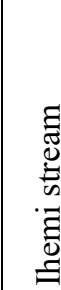 & 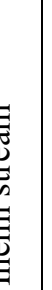 & 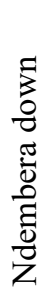 & 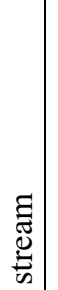 & 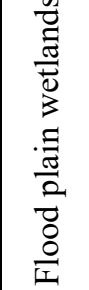 & 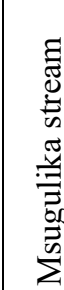 & 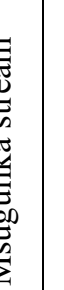 & 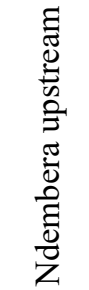 & 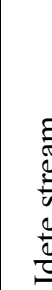 & 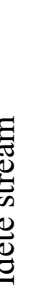 \\
\hline
\end{tabular}




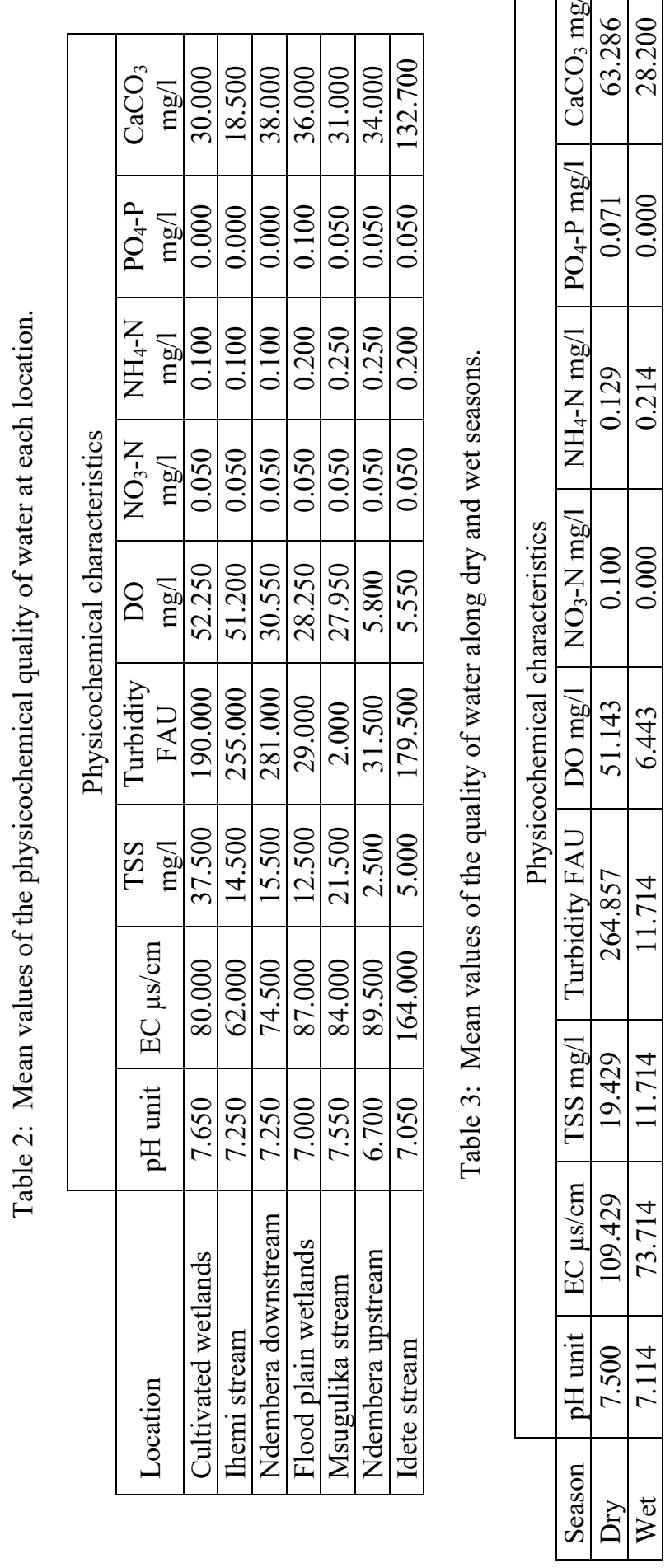


The mean dry season values of pH (7.500), EC (109.429 mg/l), TSS (19.429 mg/l), turbidity (264.857 FAU), DO (51.143 mg/l), $\mathrm{NO}_{3}-\mathrm{N}(0.100 \mathrm{mg} / \mathrm{l}), \mathrm{PO}_{4}-\mathrm{P}(0.071 \mathrm{mg} / \mathrm{l})$ and total alkalinity as $\mathrm{CaCO}_{3}(63.286 \mathrm{mg} / \mathrm{l})$ were higher than those of the wet season Table 3 .

Results from ANOVA show that there was a significant variation of the physicochemical characteristics of the TSS in all locations (Table 4) and the seasons. Also Turbidity, DO and $\mathrm{P}_{4}-\mathrm{P}$ showed a significant difference in all the seasons with a p-value of 0.0246, 0.0190 and 0.0465 respectively (Table 5).

Table 4: Separated mean values of the TSS at sampling locations.

\begin{tabular}{|c|c|c|c|c|c|c|c|}
\cline { 2 - 7 } \multicolumn{1}{c|}{} & \multicolumn{9}{c|}{ Sampling locations } \\
\hline & $\begin{array}{c}\text { Cultivated } \\
\text { wetlands }\end{array}$ & $\begin{array}{c}\text { Ihemi } \\
\text { stream }\end{array}$ & $\begin{array}{c}\text { Ndembera } \\
\text { down stream }\end{array}$ & $\begin{array}{c}\text { Flood } \\
\text { plain } \\
\text { wetlands }\end{array}$ & $\begin{array}{c}\text { Msugulika } \\
\text { stream }\end{array}$ & $\begin{array}{c}\text { Ndembera } \\
\text { up stream }\end{array}$ & $\begin{array}{c}\text { Idete } \\
\text { stream }\end{array}$ \\
\hline Mean value & $35.5^{\mathrm{a}}$ & $14.5^{\mathrm{b}}$ & $15.5^{\mathrm{b}}$ & $12.5^{\mathrm{b}}$ & $21.5^{\mathrm{c}}$ & $2.5^{\mathrm{d}}$ & $5.0^{\mathrm{d}}$ \\
\hline
\end{tabular}

Note: Mean values superscripted by different lower-case letter in the same row are significantly different following a separation by Duncan's Multiple Range Test (DMRT) at P value $<0.05$.

Table 5: Separated mean values of the TSS, Turbidity, DO and $\mathrm{P}_{4}-\mathrm{P}$ across the dry and wet seasons.

\begin{tabular}{|l|c|c|c|c|}
\cline { 2 - 5 } \multicolumn{1}{c|}{} & \multicolumn{4}{c|}{ Physicochemical characteristics } \\
\hline Season & TSS mg/l & $\begin{array}{c}\text { Turbidity (FAU) } \\
\mathrm{mg} / \mathrm{l}\end{array}$ & $\begin{array}{c}\text { DO (\% of saturation) } \\
\mathrm{mg} / \mathrm{l}\end{array}$ & $\mathrm{PO}_{4}-\mathrm{P} \mathrm{mg} / \mathrm{l}$ \\
\hline Dry & $19.429^{\mathrm{a}}$ & $264.857^{\mathrm{a}}$ & $51.143^{\mathrm{a}}$ & $0.071^{\mathrm{a}}$ \\
\hline Wet & $11.714^{\mathrm{b}}$ & $11.714^{\mathrm{b}}$ & $6.443^{\mathrm{b}}$ & $0.000^{\mathrm{b}}$ \\
\hline
\end{tabular}

Note: Mean values superscripted by different lower-case letter in the same column are significantly different following a separation by DMRT at $\mathrm{P}<0.05$.

\section{DISCUSSION}

Some marked variations of the quality water were observed along locations and the seasons. The water temperature had a range of $23^{\circ} \mathrm{C}$ to $29.2^{\circ} \mathrm{C}$. The low water temperature $\left(23^{\circ} \mathrm{C}\right)$ of the sub-catchment during the wet season could be a result of seasonal changes in air temperatures associated with the cold season experienced in the Southern Highlands of Tanzania during the wet season [13]. This temperature is within the range of $10^{\circ} \mathrm{C}-50^{\circ} \mathrm{C}$ for rivers in the tropical waters [12].

The higher mean values obtained at the dry season for $\mathrm{pH}, \mathrm{EC}$, TSS, turbidity, DO, $\mathrm{NO}_{3}-\mathrm{N}, \mathrm{PO}_{4}-\mathrm{P}$ and total alkalinity could be caused by the reduced volume of water from major streams in the area. A similar trend was observed for Katogora wetlands in Nigeria [9]. EC of water varied slightly among and within the locations. This shows that water in the study area contained similar dissolved nutrients that are responsible for carrying electric current. The highest value recorded $164.000 \mu \mathrm{s} / \mathrm{cm}$ at Idete stream may be attributed to wetlands being bisected by road and closer to settlement areas thus vulnerable to pollution. Gongden and Lohdip [14] show that surface water is very vulnerable to pollution due to its ease of accessibility to human influence while the SMUWC [13] reported EC of waters in other sub catchment of the Southern Highlands Tanzania have a high capacity for electric currents that do not vary significantly.

Nitrate - Nitrogen concentrations are mostly low $(0.1 \mathrm{mg} / \mathrm{l})$ beyond the detection limit for the analysis. Ammonia - Nitrogen results show a similar pattern. Samples collected at 
Msugulika, Ndembera upstream and in the cultivated wetlands show higher levels of Nitrogen.

The low mean values for PH (7.250 units), EC $(74.500 \mu \mathrm{s} / \mathrm{cm})$, DO $(30.550 \mathrm{mg} / \mathrm{l})$, $\mathrm{NO}_{3}-\mathrm{N}(0.050 \mathrm{~m} / \mathrm{l}), \mathrm{P}_{4}(0.000 \mathrm{mg} / \mathrm{l})$ and total alkalinity $(38.000 \mathrm{mg} / \mathrm{l})$ obtained after the intervention could be one of the positive effects of the strategy. The SMUWC [13] observed higher mean values for the similar parameters in the catchment. However, higher mean values for TSS $(15.500 \mathrm{mg} / \mathrm{l})$, Turbidity $(281.000 \mathrm{FAU})$ and $\mathrm{NH}_{4}-\mathrm{N}(0.100 \mathrm{mg} / \mathrm{l})$ have been recorded at Ndembera downstream after the intervention. This could be caused by the effect of use of agrochemicals - including fertilizer in the wetland's cultivation, thus fluctuations of these parameters in the area.

\section{CONCLUSION}

The results showed that most of the physicochemical properties of water in the study area remained broadly similar despite the intervention. This shows that the strategy alone had not greatly changed the quality of water in the area and that human-related factors such as changing land uses, use of fertilizer, runoff from farmlands, and animal grazing are among contributing factors in the poor quality of water.

\section{ACKNOWLEDGEMENTS}

Authors are grateful to Mzumbe University and the Self Steering Sustainable Social Innovation through Training and E-Research (4SITe) Programme for financial support. In addition, Mr. Revocatus Mtaki of Mkwawa University College of Education during the data analysis is gratefully acknowledged.

\section{APPENDIX I \\ RESULTS OF THE ANALYSIS OF WATER SAMPLES}

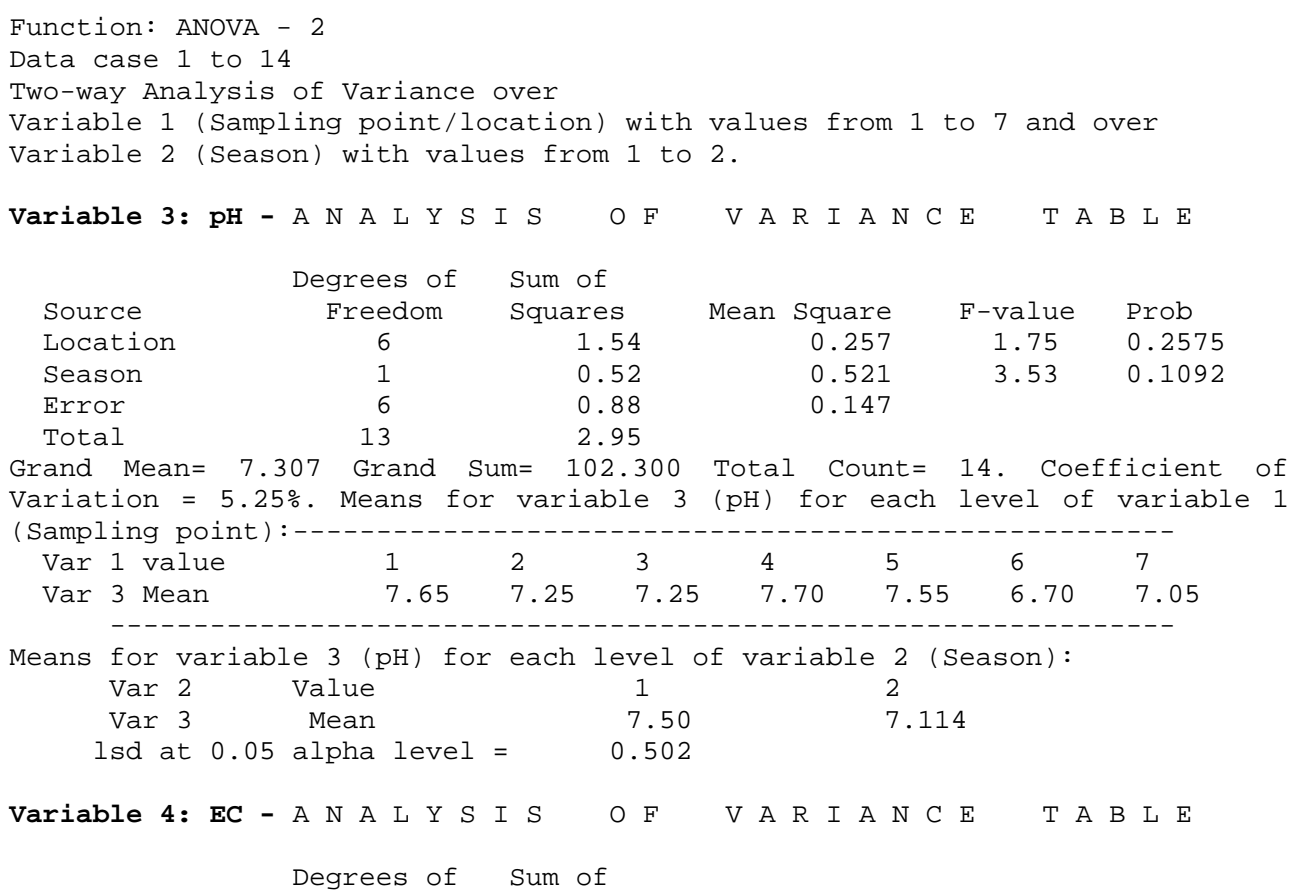




\begin{tabular}{lcr} 
Source & Freedom & \multicolumn{1}{c}{ Squares } \\
Location & 6 & 13256.43 \\
Season & 1 & 4464.29 \\
Error & 6 & 15118.71 \\
$\quad$ Non-additivity & 1 & 10862.91 \\
$\quad$ Residual & 5 & 4255.80 \\
Total & 13 & 32839.43
\end{tabular}

$\begin{array}{rcl}\text { Mean Square } & \text { F-value } & \text { Prob } \\ 2209.405 & 0.88 & 0.5614 \\ 4464.286 & 1.77 & 0.2315 \\ 2519.786 & & \\ 10862.913 & 12.76 & 0.0160 \\ 851.160 & & \end{array}$

Grand Mean $=91.571$ Grand Sum $=1282.000$ Total Count $=14$. Coefficient of Variation= 54.82\%. Means for variable 4 (EC) for each level of variable 1

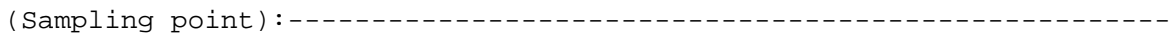

$\begin{array}{llllllll}\text { Var } 1 \text { values } & 1 & 2 & 3 & 4 & 5 & 6 & 7 \\ \text { Var } 4 \text { Mean } & 80.0 & 62.0 & 74.5 & 87.0 & 84.0 & 89.5 & 164.0\end{array}$

Means for variable 4 (EC) for each level of variable 2 (Season): $\begin{array}{ccll}\text { Var } 2 & \text { Value } & 1 & 2 \\ \text { Var } 4 & \text { Mean } & 109.429 & 73.714 \\ \text { lsd at } & 0.05 \text { alpha level }= & 65.655 & \end{array}$

Variable 5: TSS - A N A L Y S I S OF V A R I A N C E T A B L E

$\begin{array}{lcrrrl} & \text { Degrees of } & \text { Sum of } & & & \\ \text { Source } & \text { Freedom } & \text { Squares } & \text { Mean Square } & \text { F-value } & \text { Prob } \\ \text { Location } & 6 & 1618.43 & 269.738 & 9.95 & 0.0066 \\ \text { Season } & 1 & 208.29 & 208.286 & 7.68 & 0.0324 \\ \text { Error } & 6 & 162.71 & 27.119 & & \end{array}$

Grand Mean= 15.571 Grand Sum= 218.000 Total Count= 14. Coefficient of Variation $=33.44 \%$. Means for variable 5 (TSS)for each level of variable 1 (Sampling point):

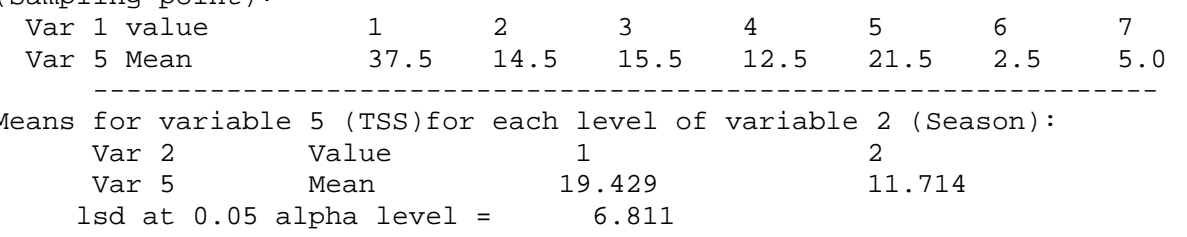

Variable 6: TURBIDITY - A N A L Y S I S OF V A R I A N C E T A B L E

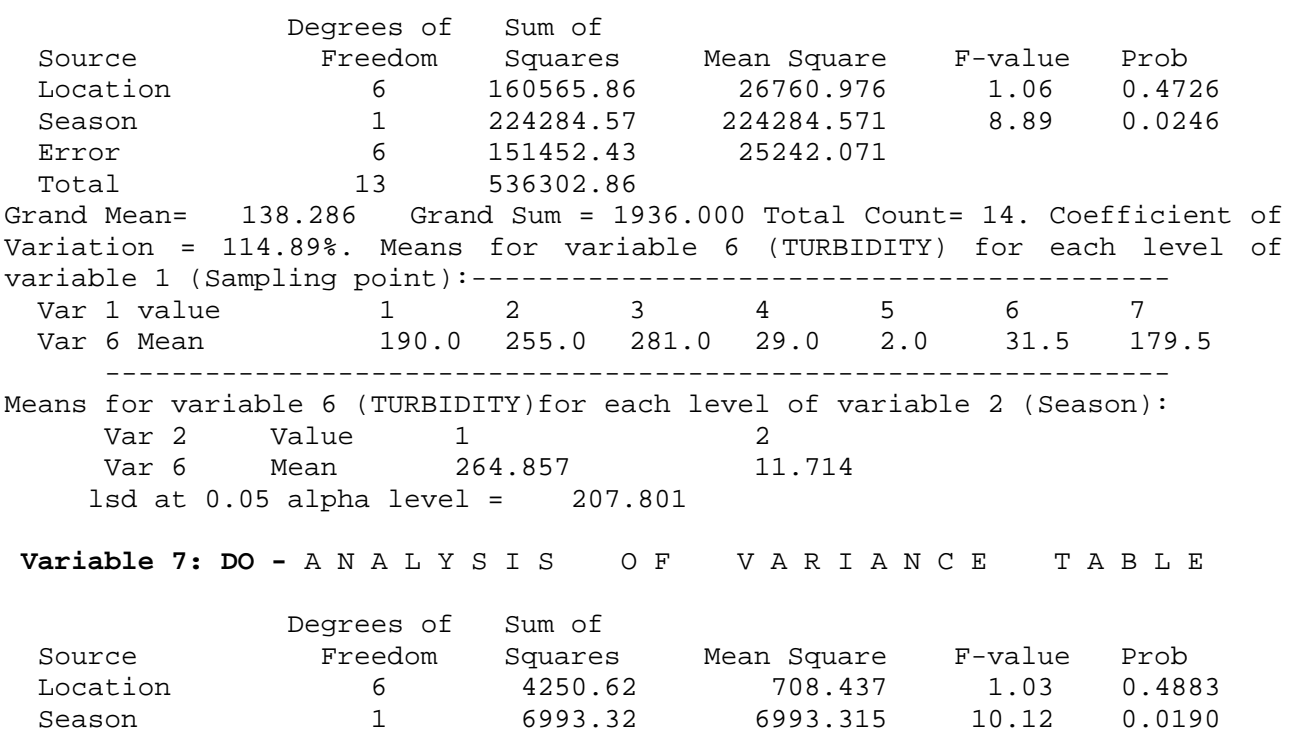




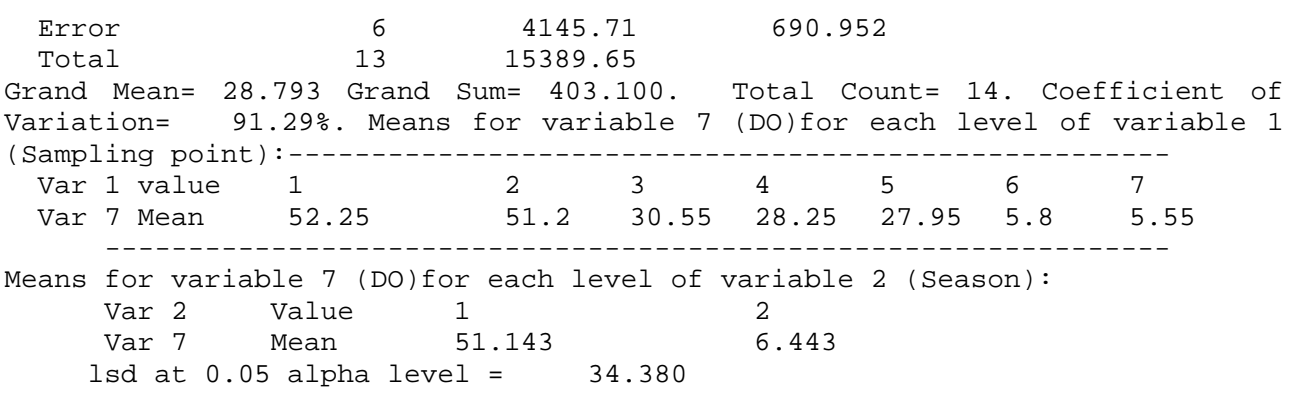

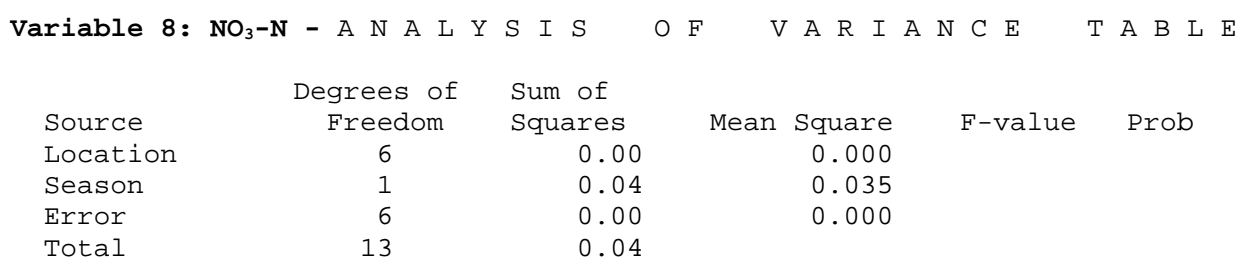

Grand Mean $=0.050$ Grand Sum $=0.700$ Total Count $=14$. Coefficient of Variation $=0.00 \%$. Means for variable 8 (N03-N)for each level of variable 1 (Sampling point):

$\begin{array}{llllllll}\operatorname{Var} 1 \text { value } & 1 & 2 & 3 & 4 & 5 & 6 & 7 \\ \text { Var Mean } & 0.05 & 0.05 & 0.05 & 0.05 & 0.05 & 0.05 & 0.05\end{array}$

Means for variable $8(\mathrm{NO3}-\mathrm{N})$ for each level of variable 2 (Season):

\begin{tabular}{|c|c|c|c|}
\hline Var 2 & Value & 1 & 2 \\
\hline Var 8 & Mean & 0.100 & $\odot .00 \odot$ \\
\hline
\end{tabular}

Variable 9: $\mathrm{NH}_{4}-\mathrm{N}-\mathrm{A} N \mathrm{~N}$ L Y S I S OF VAR I A N C E TA B L E

$\begin{array}{lcrrrl} & \text { Degrees of } & \text { Sum of } & & & \\ \text { Source } & \text { Freedom } & \text { Squares } & \text { Mean Square } & \text { F-value } & \text { Prob } \\ \text { Location } & 6 & 0.06 & 0.010 & 0.91 & 0.5435 \\ \text { Season } & 1 & 0.03 & 0.026 & 2.40 & 0.1723 \\ \text { Error } & 6 & 0.06 & 0.011 & & \\ \text { Total } & 13 & 0.15 & & & \end{array}$

Grand Mean $=0.171$ Grand Sum $=2.400$ Total Count= 14. Coefficient of Variation $=60.38 \%$. Means for variable 9 (NH4N for each level of variable 1 (Sampling

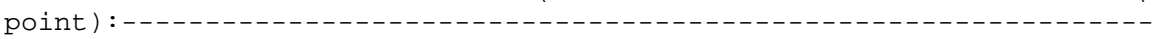

$\begin{array}{llllllll}\operatorname{Var} 1 \text { value } & 1 & 2 & 3 & 4 & 5 & 6 & 7 \\ \operatorname{Var} 9 \text { Mean } & 0.1 & 0.1 & 0.1 & 0.2 & 0.25 & 0.25 & 0.2\end{array}$

Means for variable 9 (NH4N)for each level of variable 2 (Season):

\begin{tabular}{|c|c|c|c|}
\hline Var 2 & Value & 1 & 2 \\
\hline Var 9 & Mean & 0.129 & 0.214 \\
\hline
\end{tabular}

$\begin{array}{lccrrr}\text { Variable 10: } \mathbf{P O}_{4}-\text { A N A L Y S I S } 0 \mathrm{~F} & \text { V A R I A N C E T A B L E } \\ & \text { Degrees of } & \text { Sum of } & & & \\ \text { Source } & \text { Freedom } & \text { Squares } & \text { Mean Square } & \text { F-value } & \text { Prob } \\ \text { Location } & 6 & 0.02 & 0.003 & 1.00 & 0.5000 \\ \text { Season } & 1 & 0.02 & 0.018 & 6.25 & 0.0465 \\ \text { Error } & 6 & 0.02 & 0.003 & & \\ \text { Total } & 13 & 0.05 & & \end{array}$

Grand Mean $=0.036 \quad 13$ Grand Sum $=0.500$ Total Count $=14$. Coefficient of Variation $=149.67 \%$. Means for variable 10 (P04)for each level of variable 1

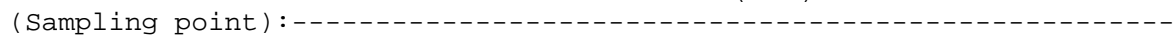




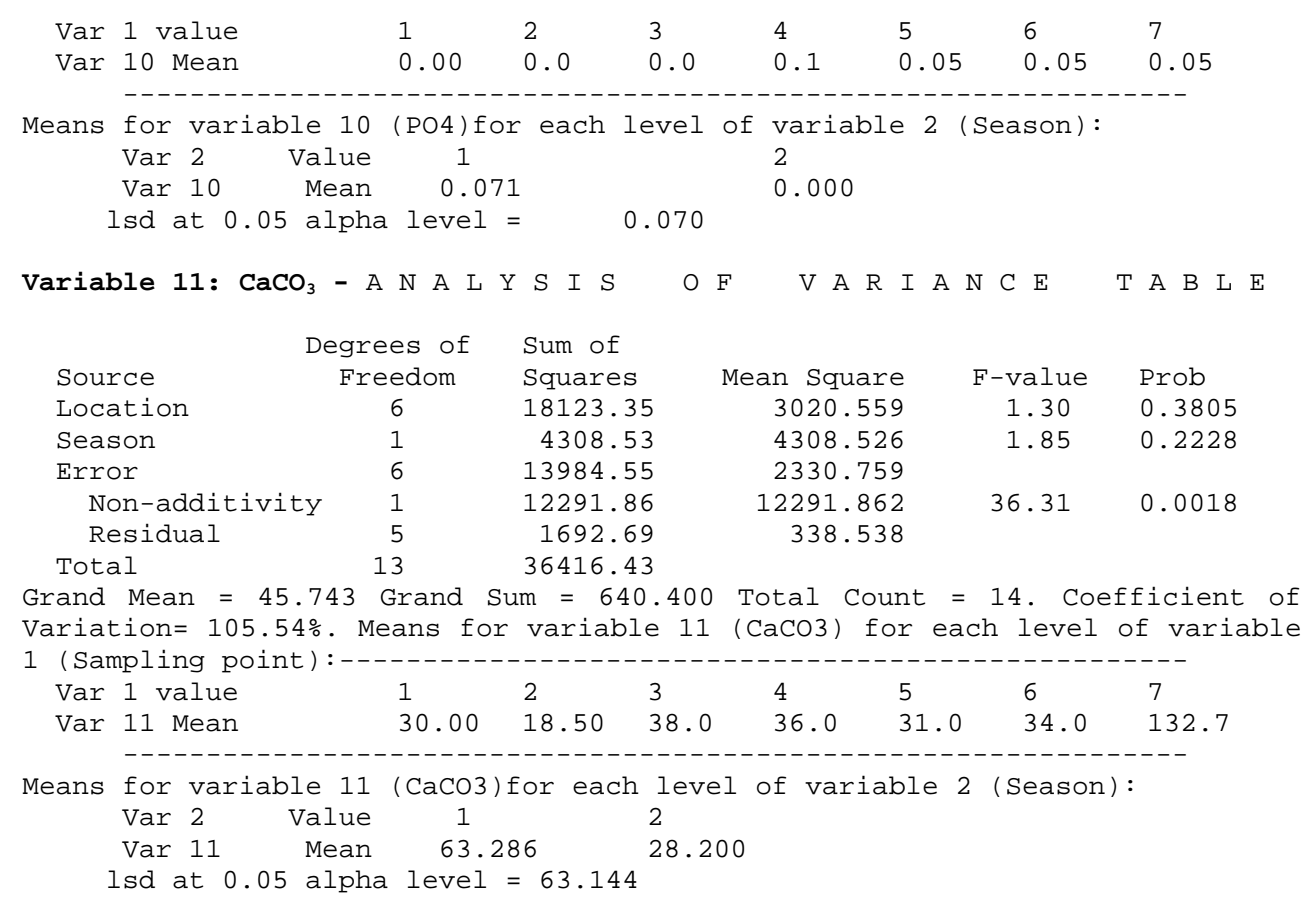




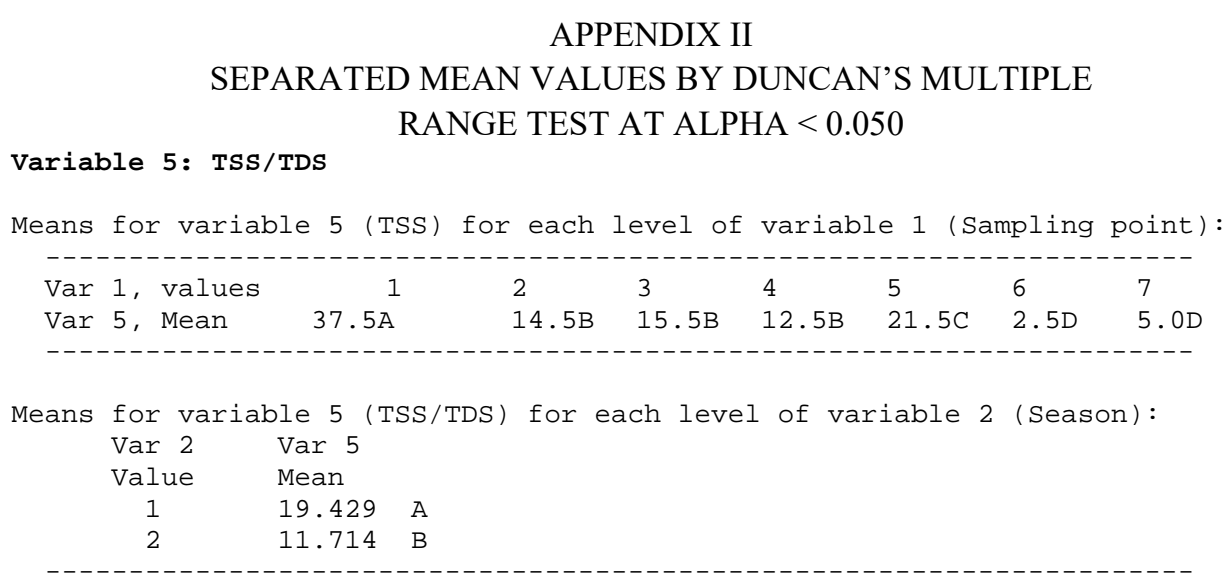

Variable 6: Turbidity

Means for variable 6 (TURBIDITY) for each level of variable 2 (Season): Var 2 Var 6

Value Mean

$1 \quad 264.857$ A

$2 \quad 11.714$ B

Variable 7: Do

Means for variable 7 (DO) for each level of variable 2 (Season):

Duncan's Multiple Range Test at alpha 0.050

$\operatorname{Var} 2 \quad \operatorname{Var} 7$

Value Mean

$1 \quad 51.143 \mathrm{~A}$

26.443 B

Variable 10: $\mathrm{PO}_{4}$

Means for variable 10 (P04) for each level of variable 2 (Season):

Var 2 Var 10

Value Mean

$1 \quad 0.071 \mathrm{~A}$

$2 \quad 0.00 \odot$ B

\section{REFERENCES}

[1] Ramsar Convention on Wetlands, FAO, International Water Management Institute (IWMI), Wetlands and Agriculture: Partners for Growth, Gland: Ramsar Convention on Wetlands; Rome: FAO; Colombo: IWMI, pp. 1-16, 2014.

[2] Gray, M.J., Hagy, H.M., Nyman, J.A. \& Stafford, J.D., Management of wetlands for wildlife. Wetlands Techniques, eds J.T. Anderson \& C.A. Davis.

DOI: 10.1007/978-94-007-6907-6-4, 2013.

[3] Ngowi, N.J., Contribution of wetland friendly investment approach on livelihoods and ecosystem services: The case of Ndembera River in Iringa, Tanzania. PhD thesis, University of Dar es Salaam, 2018. 
[4] United Republic of Tanzania (URT), Fifth National Report on the Implementation of the Convention on Biological Diversity, The Vice President's Office, Dar es Salaam, 2014. www.cbd.int/doc/world/tz/tz-nr-05-en.pdf.

[5] Ministry of Natural Resources and Tourism (MNRT), Sustainable Wetlands Management Programme Completion Report, Dar es Salaam, 2013.

[6] Ngowi, N.J. \& Mwakaje, A.G., Implementation effects of incentive policies on Tanzanian wetland ecosystems. Kasetsart Journal of Social Science. DOI: 10.1016/j.kjss.2018.05.016, 2018.

[7] Ernst \& Young, Value for money audit for participatory forest anagement and sustainable wetlands management programme. Dar es Salaam, Tanzania, p 34, 2010. http://um.dk/en/ /media/um/english-site/documents/danida/eval/987-87-7087-4724/201005annex4tanzaniacasestudy.ashx.

[8] Rufiji Basin Water Board (RBWB), Environmental and Social Impact Assessment Lugoda \& Maluluma Hydropower on Ndembera River. Environmental and Social impact assessment report. Vol 1 - report. ecoVision GmbH, Austria, pp. 275, 2015.

[9] Ibrahim, B.U., Auta, J. \& Balogu, J.K., An assessment of the physico-chemical parameters of Kantagora reservoir, Niger State, Nigeria. Bayero Journal of Pure and Applied Sciences, 2(1), pp. 64-69, 2009.

[10] Freed, R., Eisensmith, S.P., Goetz, S., Reicosky, D., Smail, V.M. \& Wolleberg, P., MSTAT-C A Microcomputer Program for the Design, Management and Analysis of Agronomic Research Experiments, Michigan State University, USA, 1990.

[11] Steel, R.G.D. \& Torrie, J.H., Principle and Procedures of Statistics, McGraw-Hill: New York, 633 pp., 1980.

[12] World Health Organization (WHO), Guidelines for Drinking Water Quality, Geneva, 211 pp., 1984.

[13] Sustainable Management of the Usangu Wetland and its Catchment (SMUWC), Water Quality Assessment Report, 39 pp., 2001.

[14] Gongden, J.J. \& Lohdip, Y.N., Seasonal variation of the surface water quality of two dams in Plateau State, north central Nigeria. Water Resources Management VIII, ed. C.A. Brebbia, WIT Transactions of Ecology and Environment, vol. 196, WIT Press: Southampton and Boston, pp. 291-298, 2015. 